\title{
IMPLEMENTATION OF CLIL AT TECHNICAL UNIVERSITY FOCUSING ON CLIL TEACHER PROFILE
}

\author{
Jaroslava Štefková ${ }^{1}$, Zuzana Danihelová ${ }^{2}$ Elena Kováčiková ${ }^{3}$ \\ ${ }^{1,2}$ Technical University, Zvolen, Slovakia \\ ${ }^{3}$ Constantine the Philosopher University, Nitra, Slovakia \\ stefkova@tuzvo.sk
}

\begin{abstract}
The submitted paper deals with the issue of CLIL implementation at the Technical University in Zvolen, Slovakia, specifically with the CLIL teacher profile and the preparedness of the university teachers to apply CLIL into their teaching practice. The topic was selected due to the ever-increasing importance of English in everyday communication and for professional, academic, and scientific purposes. The nature of the research is qualitative; therefore, the SWOT analysis was used for analysing the current state of teacher preparedness for CLIL implementation. The study was conducted using a sample of 15 university teachers teaching disciplinary subjects via a structured interview. The interviews were subsequently analyzed, considering three aspects of CLIL teacher profile: professional background and expertise, methodological preparedness, and language preparedness. Individual strengths, weaknesses, opportunities, and threats of implementing CLIL were established in the analysis. The results indicated a general lack of language and methodological preparedness of teachers. On the other hand, all interviewed teachers were eager to improve in the specific areas to teach using the CLIL methodology since they all acknowledged the importance of language knowledge. Nevertheless, students' insufficient level of language preparedness could be a threat to implementing the CLIL methodology, which could eventually discourage them from attending lectures and seminars where CLIL elements are applied.
\end{abstract}

Keywords: CLIL teacher profile; tertiary education; SWOT analysis.

\section{Introduction}

In the educational practice, teachers have been looking for the way which would be most fruitful towards their students and their self-satisfaction. In the second half of the 1990s, a new approach called CLIL (Content and Language Integrated Learning) emerged in Europe. It was also promoted by the plurilingualism movement in the European Union and covered in the Council of Europe when students should attain two foreign languages in their education. CLIL was ideal for employing the foreign language even in a content-subject lesson, so the students were exposed to the foreign language outside of language education. Adding the content to the language was also a great combination considering the language of professionals or academic field and improving the chances to study or work abroad, getting more information within the field of interest.

Although CLIL methodology focuses on learners more than the teacher, the teacher remains crucial in the pedagogical process. The teacher is mainly understood as "the knowledge-owner." However, CLIL expands the teachers' roles into facilitators to the students' learning tasks, investigators of the new information, teaching-learning material creators, promoters of CLIL, and many more. Though, the aim of this article is to address one of the crucial elements of CLIL lessons execution - the profile of the CLIL teacher. It is necessary to describe the starting state of a teachers' skills and needs to design an effective way to implement CLIL. Based on the research, we can state the following pillars of CLIL teachers - the discipline knowledge, pedagogical experience and skills, and finally, language proficiency. There are also mentioned some difficulties CLIL teachers face, including a dramatic increase in the workload and interpersonal clashes on CLIL implementation. Moreover, some authors mentioned the necessity to address the relationship between management and the teachers. On the other hand, the literature primarily deals with the description of the experience of teachers at the primary and secondary levels who have implemented CLIL to a certain extent, and there are few descriptions of CLIL teachers at the tertiary level described in the literature.

\section{Literature review}

The CLIL methodology was developed further in the next decade in well-recognised works of Marsh from 2000 to 2013, Mehisto et al. (2008), Coonan (2017), Coyle, D. et al. (2010), Meyer, O. (2010), Ball et

(C Jaroslava Štefková, Zuzana Danihelová, Elena Kováčiková. 2021. Published by Igor Sikorsky Kyiv Polytechnic Institute. This is an Open Access article distributed under the terms of the licence CC BY 4.0 
al. (2015) and others. The previous works introduced theoretical principles and practical solutions to the implementation of CLIL into the educational system. CLIL is not only bilingual education but also dualfocused education as it usually includes two languages (mother tongue and a foreign language). It also combines language and content input in various ratios. However, these specify only the very central aspect of CLIL. CLIL is defined as $4 \mathrm{Cs}$ - content, communication, culture, and community (Coyle et al., 2010) and by four other elements content, language, integration, and learning (ECML - European Center for Modern Languages, 2004-2007). ECML was developed by an international group of experts (David Marsh (Finland), Do Coyle (UK), Stefka Kitanova (Bulgaria), Anne Maljers (The Netherlands), Dieter Wolff (Germany), Bronislawa Zielonka (Poland). Their work resulted in the production of a CLIL Matrix (ECML webpage) describing 16 mutual parameters of CLIL. The Matrix goes even further, developing each parameter in a description of the real-life example and measuring the CLIL expertise by the set of several questions related to the parameter. The CLIL Matrix gives a "user-friendly" description of the complex topic of CLIL methodology. Another description of CLIL methodology is provided by Mehisto et al. (2008), who sees the main attributes of CLIL in the following parameters: multiple foci, safe and rich learning environment, authenticity, active learning, scaffolding, cooperation. The least common approach to the understanding of CLIL is presented by Meyer (2010) as the CLIL pyramid.

Based on CLIL implementation in schools at all - primary, secondary, and tertiary levels throughout the first decade of the 21st century until now, some critical issues regarding CLIL implementation have been identified. As described by Cinganotto (2016, pp. 392-393), they include the preparation of teachers, especially disciplinary teachers, as they are not prepared for team teaching with language teachers. Secondly, introducing CLIL into their instruction means a significant additional workload to prepare materials, plan lessons. Finally, their further methodological training needs to be also mentioned. Other drawbacks often perceived by teachers are the lack of materials for CLIL lessons tailored according to the content and language level requirements and the dual assessment of CLIL lessons. CLIL implementation in Slovak higher education has been followed by only a few researchers (Hurajová and Luprichová, 2017;Chmelíková and Hurajová, 2019; and Kováčiková, 2020). Hurajová (2021) addressed the need for cooperation between the teachers of professional courses and language teachers in higher education. Kováčiková presented the concept of educating young teachers on CLIL principles at a teacher training college level.

Further, the studies of D'Alessio and Hardie (2019) looked into the specifics of CLIL depending on the type of school (from primary to university). They focused on implementing CLIL in the university context and bachelor degree students at the University of Applied Sciences and Arts of Southern Switzerland. They found a possible gap between relatively low learners' language mastering and rather complex content learning. In his study, Yang (2016) assessed the efficacy and effectiveness of employing CLIL in higher education in Taiwan. In the following study, he (2018) discussed the factors affecting CLIL materials' perception within CLIL application in the National Polytechnic University in Taiwan. Still, further insights and deeper analyses are necessary in order to gain broader perspectives on this issue.

\section{CLIL teacher profile}

As seen in the previous section, the CLIL teacher is of utmost importance in the whole process of CLIL implementation. He is not only a doer of the instruction itself, but in many cases, they train to master CLIL, and at the same time, they promote CLIL in the eyes of the school environment, including passive colleagues who have not decided for CLIL yet (Infante, Benventuto, and Lastrucci, 2009).

The profile of a teacher, in general, includes several aspects, mainly in non-measurable instances such as $\mathrm{He} / \mathrm{she}$ is friendly, motivating, inspiring, patient, positive, open-minded, respectful (Sadker, 1991 in Turek, 2010) or He/she ... can explain the content well, ... can use time efficiently, ... knows his/her subject very well (Black, Howard -Jones, 2000 in Turek,2010); he/she seeks for constant improvement of his/her work, can communicate well with students, parents (Young and Shaw, 1999 in Turek, 2010), etc. Another big-scale research (Education International, Oxfam Novib, 2011) towards teachers competence profile conducted questionnaires and interview with various stakeholders including stakeholders, such as teachers' unions, teachers, teacher trainers, the Ministry of Education, the Education Secretaries of States and universities in South Africa, New Zealand, Canada, Chile, Brazil, India, Malaysia, the Netherlands, Slovenia, Mali, and Uganda. The research came to the following results stating some personal qualities: patient, flexible, open-minded, dynamic; pupil/student-centred qualities: "likes children" (p.78), "cares for children" (p.99), "listens to pupils, supports pupils, sees them as human beings with dignity" (p.119), not forgetting professional knowledge and skills and knowing the subject matter well. One of the profiles also mentions being sensitive towards different backgrounds and having managerial abilities. Most of them agree on constant professional development. 
However, there should be some new aspects to the CLIL teacher profile. The discussion on the differences or distinguishing qualities of CLIL teachers from teachers, in general, is developed in several works.

We looked at the CLIL teacher profile from different angles: prescribed profile for the education of CLIL teachers, a reflection of experienced teachers, and a comparison of views of content teachers and English language teachers.

As one of the CLIL implementation leading countries, Italy introduced CLIL as mandatory in secondary schools in 2013 in the Reform Law (Eurydice, 2013) and determined CLIL teacher profile (Table 1).

Table 1. CLIL teacher profile (the Italian Ministry of Education, Decree of 16th April 2012) (Cinganotto, 2016)

\section{Language dimension: The teacher}

- has a $\mathrm{C} 1$ level of competence in the foreign language (CEFR)

- is able to manage, adapt and use subject materials in the foreign language

- has a mastery of the specific subject language (specific lexicon, discourse types, text genres and forms) and of the subject concepts in the foreign language.

\section{Subject dimension: The teacher}

- is able to use the subject knowledge according to the national curricula of the relevant school level

- is able to teach the subject content integrating language and content.

Methodological dimension: The teacher

- is able to plan CLIL paths in cooperation with language teachers and teachers of other subjects

- is able to find, choose, adapt, create materials and resources to enhance the CLIL lesson also using ICT

- is able to plan a CLIL path autonomously, using methodologies and strategies aimed at fostering the learning of content through the foreign language

- is able to identify, create and use assessment tools that are consistent with CLIL methodology.

Based on the Decree and stated profile of a CLIL teacher, training courses addressed to in-service nonlinguistic subject teachers were designed. The courses covered especially language education and methodological courses focused on CLIL.

The second research dealt with the reflection on CLIL from experienced teachers conducted by Infante et al. (2009). Reflections on CLIL experience were collected and complemented by their views on collaboration within the community and materials they used in CLIL lessons. The findings include important messages that CLIL "changes the way teachers teach outside CLIL context," bringing methodological innovations and new good practices into the everyday life of teachers making their instruction "more flexible and organic." On the other hand, it also brought up some issues which need to be addressed. From the practical point of view, teachers requested "substantial and systematic training" and creating a network or CLIL community for exchanging materials and experiences. Additionally, teachers experienced "the lack of materials available, the absence of collaboration in the planning stage," and they also had "some difficulties in properly integrating content and language and creating an authentic and real setting in the classroom" (Infante et al. 2009, p.162).

Mesmaeker and Lochtman (2014) researched perceptions of CLIL teachers. The authors use a threepillar approach considering CLIL teacher's professional orientation (a teacher's job as an innovative, creative, and team-playing professional). They are task orientation (taking a pupil-oriented or content-oriented approach) and self-efficacy (teacher's motivation, commitment, and enthusiasm), mostly based on teachers' knowledge and beliefs. The results indicate that CLIL teachers rely on and wish to have collegial teamwork and joint responsibility for the lessons. On the other hand, the CLIL teachers have a more balanced view of the instruction of content and language-focused lessons; however, they require more pedagogical literature and training on the instruction of integrated teaching.

As CLIL combines two teaching areas: content and language, we were also interested in comparing how teachers perceive the difference between language and content subjects as teaching the language is considered different from teaching other subjects. This topic was examined by Haukas et al. (2021). The 
overall impression that teaching a language is more stressful than other subjects was supported by the argument that teachers and students suffer from language anxiety when communicating in the classroom. A foreign language belongs to a person's whole social being, personal identity, cultural identity, and social behaviours. Nevertheless, opposite to this, more autonomy is experienced within the language subjects. An essential factor bringing more students engagement is that teaching the language includes teaching life skills that need to be practised regularly. Comparison with other non-language subjects also mentioned different pay scales and different attitudes of students and society towards the subject (especially to the language, which is sometimes affected by political mindset). The items remaining in common for both subjects included a need to maintain the teachers' professional skills (language, music, fitness), not omitting their pedagogical training.

Another approach towards teaching language and non-language subjects was investigated by Novotná et al. (2001). The specific combination of mathematics and English was presented by bilingual education. The primary abilities of CLIL teachers consist of a good command of the language and adapting their instructional support to scaffold the students towards achieving mathematical competencies. The final description of a CLIL teacher depicts him/her as a teacher mastering content-language, being able to contextualise the content and break down and reassemble the new items of the content embedded in a positive, supportive, praising and safe atmosphere for students (Novotná et al., 2001).

Regarding the research tool, SWOT analysis was chosen. Despite SWOT analysis being a framework used to evaluate a company's competitive position and to develop strategic planning (Kenton, 2021), it has also been used in educational research (Fardani et al., 2020; Alneyadi, 2021; Harausová and Luprichová, 2017; Kováčiková and Prokeinová, 2012). This research instrument enables systematic analysis of more aspects and thus helps in decision-making processes. It was also used in the research study to evaluate interviews with students regarding their perception of online education (Hergüner, 2021). Another research carried out by Longhurst et al. (2020) used SWOT analysis to evaluate the data collected from a questionnaire focused on the current online method of anatomic education. Similarly to the present research study, the authors also assigned the selected themes to one of the four areas of the SWOT analysis. Most commonly, "SWOT analyses are used at the organizational level to ascertain how well a particular project is performing" (Shewan, 2021). The wide range of SWOT analyses used in the educational field concludes the research used to show the self-learning potential of the Communicative English Language Skill Improvement Programme in the study by Alcantud Díaz and Soler Pardo (2020). However, the quantified analysis has been conducted very scarcely.

One example of the use is provided by (Chang and Huang, 2006). The four descriptors are divided into controllable internal descriptors such as Strengths listing the qualities separating the project or organization from its competitors, in our case, other universities. Weaknesses specify the factors stopping the organization from performing well. Furthermore, there are uncontrollable external descriptors, particularly Opportunities describing only favourable external factors, which might give an advantage over the competitors, and Threats, which cannot be affected by internal factors. Threats usually mention something that might harm the organization or the project (Kenton, 2021). Four strategies depend on the strongest quadrants from the internal and external factors (Váchal andVochozka, 2013). They are:

Strengths - Opportunities - an offensive strategy - using internal strengths to take advantage of opportunities.

Strengths - Threats - defensive strategy - using strengths to minimise threats.

Weaknesses - Opportunities - cooperation strategy - improving weaknesses by taking advantage of opportunities.

Weaknesses - Threats - elimination strategy - working to eliminate weaknesses, sometimes it leads to liquidation or closing the company.

\section{Aim and hypothesis}

To describe the starting point for CLIL implementation, we focused on the subject teachers we need to know the language background, expertise background, professional-pedagogical skills, and views on the feasibility of CLIL implementation at the technical university. Defining a CLIL teacher profile seems to be a very complex and rather personal topic that involves not only knowledge but personal subjective beliefs and attitudes towards the profession of a teacher. The research aims to describe the situation using various sources, mainly interviews, to state the variables or conditions which need to be addressed before implementation of CLIL. The crucial ingredients of the CLIL are teachers, so we need to find out the main issues they are struggling with and the advantages we can rely on in CLIL implementation. 
Other influencing factors might include the level of the educational institution since it affects the content of the lessons and the functional management at the school. The following research was conducted to identify and evaluate university teachers' CLIL potential at the Technical University in Zvolen, Slovakia. The CLIL potential is defined as the competencies and willingness of the university educators teaching professional subjects (subject teachers) to implement CLIL methodology in their future teaching. The research is based on the three pillars (cf. Eurydice, 2013), i.e., subject field knowledge and teaching practice in that particular subject, foreign linguistic competencies (primarily English), and acquisition of CLIL methodology.

The main research questions to be answered in the research are:

1. Are professional teachers ready to implement CLIL methodology into their teaching?

2. What are their strengths to support the implementation of CLIL?

3. Which weaknesses of teachers need to be dealt with to implement CLIL?

4. Are there any other parameters that might affect the implementation of CLIL at the tertiary level of education?

The answers to these questions shall provide the basis for further development, which can then be planned according to the Strategic Management Model (SMM) of Wheelen and Hunger (2012). SMM starts with Environmental Scanning, which means gathering the information, entering data into SWOT quadrants. The first stage is followed by Strategy formulation consisting of Mission, Objectives, Strategies, Policies leading to Strategy Implementation umbrellaing Programs, Budges, Procedures and finishing the whole development with Evaluation and Control checking the actual results. The result of this paper shall be to decide on the strategy which could be developed into objectives and plans to implement the strategy.

\section{Methodology of Research \\ Research Design}

This research is qualitative and inductive; it stems from the data from the analysis of the interviews with fifteen university educators from the faculties provided under the Technical University in Zvolen, namely the Faculty of Wood Sciences and Technology, Faculty of Forestry, and Faculty of Technology.

\section{Participants}

Fifteen teachers were divided into three groups according to the length of their teaching practice, understanding that there might be common features. Group 1 covered four university teachers with teaching practice from one to ten years. Group 2 consisted of five educators teaching from fourteen to 25 years and Group 3 with six teachers with their teaching practice ranging from 20 to 35 years. The assumption for the division was that the length of the teaching practice predetermines their teaching practices, beliefs, and attitudes (cf. OECD, 2009). The answers from the interviews were recorded.

The individual groups taking part in the research are described as follows:

\section{Group 1 - Ph.D. students and young teachers ( 1 - 10 years of practice $), 4$ participants}

Level of English: B1, B1-B2, to B2

Subject knowledge:

They all have solid subject knowledge as they have completed the second degree of education (Master's degree) two of them have completed Ph.D. studies. None of them has experienced the practice. Their only working experience is teaching at university. However, they have some understanding of the content of the subject. There is a view that there is too much theory that the students would not use in practice. They all see a lack of practice at the university; therefore, they suggest on-site practice in companies or include real-life topics into the discipline's content.

English language preparedness:

Based on their previous language studies, they all judge their B1 to B2 level; they can use English to study and teach. They claim that reading technical articles improved their knowledge of English most. However, they still miss-communication practice. Using English in teaching might be a significant help in practising at least some spoken language. Using English in their teaching is seen as a challenge and method of professional and personal growth.

On the other hand, it would impose stress and even fear on one of them. To reduce the stress and support confidence in teaching in English, they would welcome and appreciate the consultation and cooperation with the language department at the university. Other means of language progress are foreign stays, including Erasmus mobilities, expertise lectures in English. Teaching international students would mean a powerful urge to prepare and teach in English. Teaching Slovak students in English would require 
dividing them into language categories so that the most advanced students would understand English instruction and technical content simultaneously. The less English skilled students are seen as impossible to be taught in English as there would be no or very little understanding of the technical content.

To summarise their relationship towards English, it can be stated that they understand the prevailing importance of English in the academic environment, and their mastering of English is already at the CLIL applying level. Finally, they are eager to use English in their teaching and consider this a natural way for their competence growth.

\section{Pedagogical background:}

This group consists of young and relatively pedagogically uneducated teachers. One of them has completed a teacher training course, and the rest of them have not completed it yet. The absence of pedagogical training is reflected in using a narrower range of activities in their lessons and struggle in managing the lessons (difficulty to provoke discussion, copying their previous teachers' methods, lack of innovative teaching methods, no e-testing). However, they would like to improve their pedagogical skills and learn methods or approaches, including implementation of CLIL into lessons. The activities they often use include teacher-student communication, student presentation, real-life-like projects. They mostly want to participate in a teacher training course designed to teach university students and be enriched by rhetoric. One of the interviewees commented on another aspect of their work that "the management of university focuses more on scientific publishing than on working with students," which naturally carries side-effects degrading the quality of instruction and motivation of teachers to implement innovative teaching methods.

\section{Group 2 - University teachers with 11 - 25 years of practice, 5 participants}

Level of English: B1 - C1

Subject knowledge: the professional background of all the interviewed teachers is similar; they have completed their Ph.D. They have been teaching specific fields of expertise, from technical to business specializations. All of them are trying to employ authentic materials and bridge the theory. However, in general, they describe the university environment as a place that does not connect with the practice. They also critically comment on little collaboration among their colleagues.

English language preparedness: Three out of five do not feel very confident in spoken English; their linguistic self-confidence is stronger in receptive than productive skills. However, all of them realise the importance of internationalization and the necessity to learn foreign languages. Their linguistic learning history involved working with professional materials, writing papers, and participating in international events. Thus, English is a part of their professional lives. They all motivate students to learn English and use it whenever possible. All the participants realise that the academic environment requires the use of English.

Pedagogical background: Four participants completed a methodological course apart from their professional expertise. One of the respondents has not taken part in any methodological preparation on how to teach. All of them claim that they bridge theories with the practice, with lots of demonstrations and examples from professional practice, interactive teaching with pair or group works, discussions, debates, development of critical thinking, use of visuals, argumentative techniques, use of authentic materials, use of guest lecturing. As for the weaknesses, the design of a lecture as a "one-woman show" is perceived by one of the participants as required. Three out of five participants commented on the students' immaturity in thinking, preparing, and presenting a quality project. However, this changes with the degree of students, the master's degree students are usually more active and better to work with. Another critical remark was given to students with special needs as it is difficult to adjust the learning environment for them. One out of five respondents is ready to teach her courses in English, and she has already tried teaching the contents of specific subjects through English. Others find teaching their courses in English demanding and lack their linguistic competencies. From the point of view of lesson planning, they all request methodological and linguistic support. They understand the future of CLIL as a collaboration of language and content teachers. All but one claims the relevance of teaching professional content through English for Slovak classrooms only; however, they primarily see the future in engaging international students.

\section{Group 3 - Professors and Assistant professors (20 - 35 years of practice), 6 participants}

Level of English: A1, B2 - C1

Subject knowledge:

The professional background of all the participating teachers is similar; all of them completed university education $(\mathrm{PhD}$.), and they have long practice with teaching in their specific fields of expertise (civil engineering with the focus on fire protection, civil engineering with the focus on timber structures, various chemistry aspects in the field of fire protection, climatology, wood-based materials, and fire and rescue services). Three teachers also have rich experience from practice in addition to their academic and scientific 
activities. The other three teachers have never been genuinely involved in practice; they have only worked at the university as teachers or at other positions. However, they cooperate, to a certain extent, with professionals from practice. Most teachers declared that they connect the curriculum with practice and practice requirements to demonstrate to students the importance of mastering the things they learn. Moreover, they mentioned specific examples of how the students are involved in various practical activities during either hands-on training, a compulsory part of the particular study programme, or other extracurricular activities carried out in collaboration with other professional organizations and companies. However, three respondents (those with experience from practice) mentioned that the interconnection between university studies in general and practice is not sufficient.

English language preparedness:

The level of foreign language skills varies greatly within the group. The first foreign language of neither of the respondents was English. They started learning the English language either during their university studies or in other individual language courses with native speakers. The four professors also completed various study stays and professional internships abroad (Finland, Denmark, USA, China), which greatly added to their language development. All of them, except one, mentioned that they could read professional and scientific papers in English with comprehension. One of the respondents regularly includes English in her lectures, where at the end of each lecture, she summarises the essential information in English. Another respondent has rich experience lecturing in English on various topics from his field of expertise (online lectures for students at other universities abroad) and even interpreting at various professional events and fares. Three respondents also declared the ability to write scientific papers in English.

Half of the teachers claimed they would find it rather impossible, complex, or stressful to communicate in the English language spontaneously. However, all of them agreed that it is crucial to master the English language to succeed in the scientific and academic context. Furthermore, all of them would appreciate cooperation with language professionals to incorporate CLIL in their lectures and increase their language confidence. Since all of them acknowledged the importance of the English language, they would also encourage students, mostly the Ph.D. students, to participate in the Erasmus+ programme to practice the English language and become more fluent and experienced in using the language in a specific science context.

All the teachers, except one, highlighted the unquestionable benefits of using English in their courses for students. Nonetheless, one teacher did not see any benefits of incorporating English into the classes since the students need to master the subject knowledge, mostly related to legislation, in Slovak. Despite the declared necessity and benefits of using English in the classes, all the approached teachers identified one common threat: the inability of some students (with a low level of language competence) to comprehend the lecture content if presented in English.

Pedagogical background

Since the respondents received their education in the science field, all of them also completed the additional teacher training course. Three participants agreed that the course was not satisfactory because the content focused on the lower secondary and secondary school teaching rather than on university teaching. Therefore, some of them voluntarily took part in other teacher training courses in Slovakia or abroad (as part of professional internships of mobilities). Nevertheless, all of them expressed willingness to update their knowledge in this field regularly.

All the participating teachers actively participate in the education process; they mostly give lectures and have seminars to a certain extent. They use a wide range of teaching methods during lectures. The most often mentioned methods were discussion, asking questions, and actively involving students in the lecture. In addition, if the number of students in the course allows, they try to address the students individually and consult their projects or assignments. In several cases, the teachers mentioned that the method selection is course-dependent, and they vary the methods according to the course requirements and students.

\section{Instruments and Procedure}

The semi-structured interview (cf. Cohen, Manion, Morrison, 2007; Flick, 2009) covered fifteen questions in three areas. (See The interview questions in the Appendix). The first part discussed the teaching experience with professional subjects, the second part the linguistic experience and foreign language competencies. In the last part, the participants were asked about the possibilities, willingness, and challenges when possibly implementing English or another foreign language in teaching professional subjects (CLIL). The interviews were conducted online due to the pandemics restricted conditions from February until June 2021. All the participants provided consent for their talks to be recorded and processed for further research.

SWOT analysis was used to evaluate the data from the interview. Coding the statements into strengths, weaknesses, threats, and opportunities was conducted by three researchers who objectively assessed the 
answers into the three directions mentioned earlier, i.e., teaching experience, foreign language competencies, and their attitudes towards CLIL implementation. In the direction of this research, the collected data were analyzed and evaluated. The numerical assessment of individual quadrants (strengths, weaknesses, opportunities, threats) was carried out to decide the final strategy.

Additionally, two other interviews were conducted, namely with the Head of the Human Resources Department and Vice-Rector of the Technical University responsible for pedagogical performance at the university. They were asked a few questions about requirements for the job profile applied at the job interviews and about the criteria to assess the quality of teaching at the Technical University in Zvolen.

The following procedure is carried out according to Wheelen and Hunger (2012, p. 126). The factors are listed in the first column. Then, each factor is rated according to its importance in CLIL implementation by numbers from 1 - the least important to 5 - the most important. The importance refers to the subjective understanding of the whole process. Each factor is then allocated the weight it holds according to the impact on the CLIL implementation process considering the frequency it was mentioned in the interviews. This provides an objective dimension to the analysis. The sum of weights in one quadrant shall equal 1.0. Weighted Score of every factor is calculated by multiplication of Rating and Weight. Consequently, the individual weighted scores are added in each quadrant supplying the final Weighted Scores of Strengths, Weakness (which are considered a negative value), Opportunities, and Threats (having a negative value, too) and drawn in the graph. (See Figure 1.) As Furgison (2019) and Váchal and Vochozka (2013, p. 434) say, we can then decide on the best strategy for our organization or a project.

Data Analysis

The general statements of SWOT analysis for individual groups are described as follows:

Group 1 - Ph.D. students and young teachers $(1-10$ years of practice)

The overall characteristics of SWOT analysis stress the willingness to improve all their skills, including language and pedagogical skills. The main weakness outlined the lack of real-life practice, which could be reflected in their teaching and content of the curriculum, lack of pedagogical education. External factors which they see that could affect CLIL implementation are some external force (a command or appraisal) from their supervisors or the university management. The threat that could negatively affect the future is decreasing number of motivated students who can master English sufficiently.

\section{Group 2 - University teachers with 11 - 25 years of practice}

The SWOT characteristic describes this group as strong in pedagogical skills and perceiving the importance of English at the tertiary level. Generally, their greatest weakness is the ability to use English as a medium of instruction. They also experience a lack of cooperation among teachers. The threat experienced by these teachers states students' immaturity for higher-thinking-skills tasks. The teachers see the possible solution in the methodological and language support.

\section{Group 3 - Professors and Assistant professors ( 20 - 35 years of practice)}

When considering this group in terms of SWOT analysis, it can be concluded that the common strength of all the interviewed teachers is their strong professional background, extensive and rich professional experience, and subject knowledge. In addition, another strength is the language proficiency enabling them to incorporate the English language into their classes and expressed determination to take part in possible teacher training update courses. Most teachers would also welcome the possibility to cooperate with language teachers. On the other hand, a situation that would encourage most teachers to include the English language into their classes and improve their foreign language competence is the presence of international students. A threat identified by many of the interviewees was the possible insufficient level of student English language competence that could have a somewhat discouraging effect.

\section{Ethical Issues}

The participants were interviewed based on their oral agreement with recording the interviews and processing the data from the interviews. There were no objections against mentioning the extracts of the interviews anonymously in any scientific article.

\section{Results and Discussion}

The data from the individual participants within the groups were recoded according to the SWOT analysis parameters, i.e., divided into Strengths, Weaknesses, Opportunities, and Threats. The results of the re-coding can be found in the final SWOT analysis table (Table $2 \mathrm{a}, \mathrm{b}$ ). The table provides overall results, their weights, and rating determining the final scores for the quadrants. 
Table 2a. SWOT analysis - overall results: internal factors matrix

\begin{tabular}{|c|c|c|c|c|c|c|c|}
\hline \multicolumn{8}{|c|}{ Internal factors } \\
\hline STRENGTHS & Rating & Weight & $\begin{array}{l}\text { Weighted } \\
\text { Score }\end{array}$ & WEAKNESSES & Rating & Weight & $\begin{array}{l}\text { Weight } \\
\text { ed } \\
\text { Score }\end{array}$ \\
\hline $\begin{array}{l}\text { - expertise in their } \\
\text { scientific fields of } \\
\text { teaching - completed } \\
\text { academic degrees }\end{array}$ & 5 & 0.2 & 1 & $\begin{array}{l}\text { lack of experience with } \\
\text { working in practice, } \\
\text { only academic } \\
\text { experience }\end{array}$ & 3 & 0.1 & 0.3 \\
\hline $\begin{array}{l}\text { - implementation of } \\
\text { established teaching } \\
\text { approaches and } \\
\text { methods (based on } \\
\text { practical issues, project } \\
\text { work, individual or } \\
\text { group presentations) }\end{array}$ & 3 & 0.1 & 0.3 & $\begin{array}{l}\text { missing interconnection } \\
\text { between the real-life } \\
\text { practice and academic } \\
\text { assignments }\end{array}$ & 3 & 0.1 & 0.3 \\
\hline $\begin{array}{l}\text { - willingness to } \\
\text { implement CLIL into } \\
\text { their teaching (mainly } \\
\text { due to } \\
\text { internationalization) }\end{array}$ & 4 & 0.4 & 1.6 & $\begin{array}{l}\text { speaking English - the } \\
\text { crucial problem }\end{array}$ & 5 & 0.6 & 3.0 \\
\hline $\begin{array}{l}\text { - willingness to } \\
\text { cooperate with } \\
\text { language teachers in } \\
\text { preparation of CLIL } \\
\text { activities/lessons using } \\
\text { English for academic } \\
\text { purposes }\end{array}$ & 4 & 0.3 & 1.2 & methodological abilities & 3 & 0.2 & 0.2 \\
\hline & & 1.0 & 4.1 & & & & \\
\hline
\end{tabular}

Table 2b. SWOT analysis - overall results: external factors matrix

\begin{tabular}{|c|c|c|c|c|c|c|c|}
\hline \multicolumn{8}{|c|}{ External factors } \\
\hline OPPORTUNITIES & Rating & Weight & $\begin{array}{l}\text { Weighted } \\
\text { Score }\end{array}$ & THREATS & Rating & Weight & $\begin{array}{l}\text { Weight } \\
\text { ed Score }\end{array}$ \\
\hline $\begin{array}{l}\text { methodological } \\
\text { support for university } \\
\text { teachers in teaching } \\
\text { young adults, } \\
\text { including CLIL }\end{array}$ & 3 & 0.3 & 0.9 & $\begin{array}{l}\text { non-existing } \\
\text { methodological courses } \\
\text { for university teachers for } \\
\text { teaching young adults }\end{array}$ & 2 & 0.4 & 0.8 \\
\hline $\begin{array}{l}\text { - language courses in } \\
\text { order to develop } \\
\text { productive skills in a } \\
\text { foreign language }\end{array}$ & 4 & 0.4 & 1.6 & $\begin{array}{l}\text { decreasing preparedness } \\
\text { of students for university } \\
\text { studies in terms of } \\
\text { knowledge and } \\
\text { motivation }\end{array}$ & 3 & 0.4 & 1.2 \\
\hline $\begin{array}{l}\text { appraisal of extra input } \\
\text { and effort of teachers } \\
\text { teaching through a } \\
\text { foreign language to } \\
\text { motivate them }\end{array}$ & 3 & $.2^{0}$ & 0.6 & $\begin{array}{l}\text { weak language } \\
\text { preparedness of students }\end{array}$ & 5 & 0.2 & 1.0 \\
\hline \multirow[t]{2}{*}{$\begin{array}{l}\text { - cooperation among } \\
\text { international university } \\
\text { teachers (lectures, } \\
\text { Erasmus stays) }\end{array}$} & 2 & 0.1 & 0.2 & & & & \\
\hline & & 1.0 & 3.3 & & & 1.0 & 3.0 \\
\hline
\end{tabular}


As seen in the matrices of internal and external factors, each quadrant has one item with outstanding value. Within the internal factors, it is a willingness to implement CLIL into the teaching (1.2), and on the other hand, speaking English (3.0) remains the crucial problem for most teachers. The external factors point out there is a need for language courses to develop productive skills (1.6) confronted with decreasing students' preparedness for university studies in terms of knowledge and motivation (1.2). The calculation of the final Score works as adding weighted scores of strengths and weaknesses in internal factors and adding weighted scores of opportunities and threats in external factors. However, it needs to be understood that Weaknesses and Threats bear a negative value. That is how we came to the final Score of the Internal factors is -0.1 and of the External factors +0.3 , which is described as the red octangle in Figure 1. This result suggests the strategy of Weaknesses and Opportunities.

The future development strategy that resulted from SWOT analysis is the Weaknesses and Opportunities strategy, where we should focus on working on the weaknesses by giving a chance to opportunities, which in our case, matches the same issue - language speaking ability.

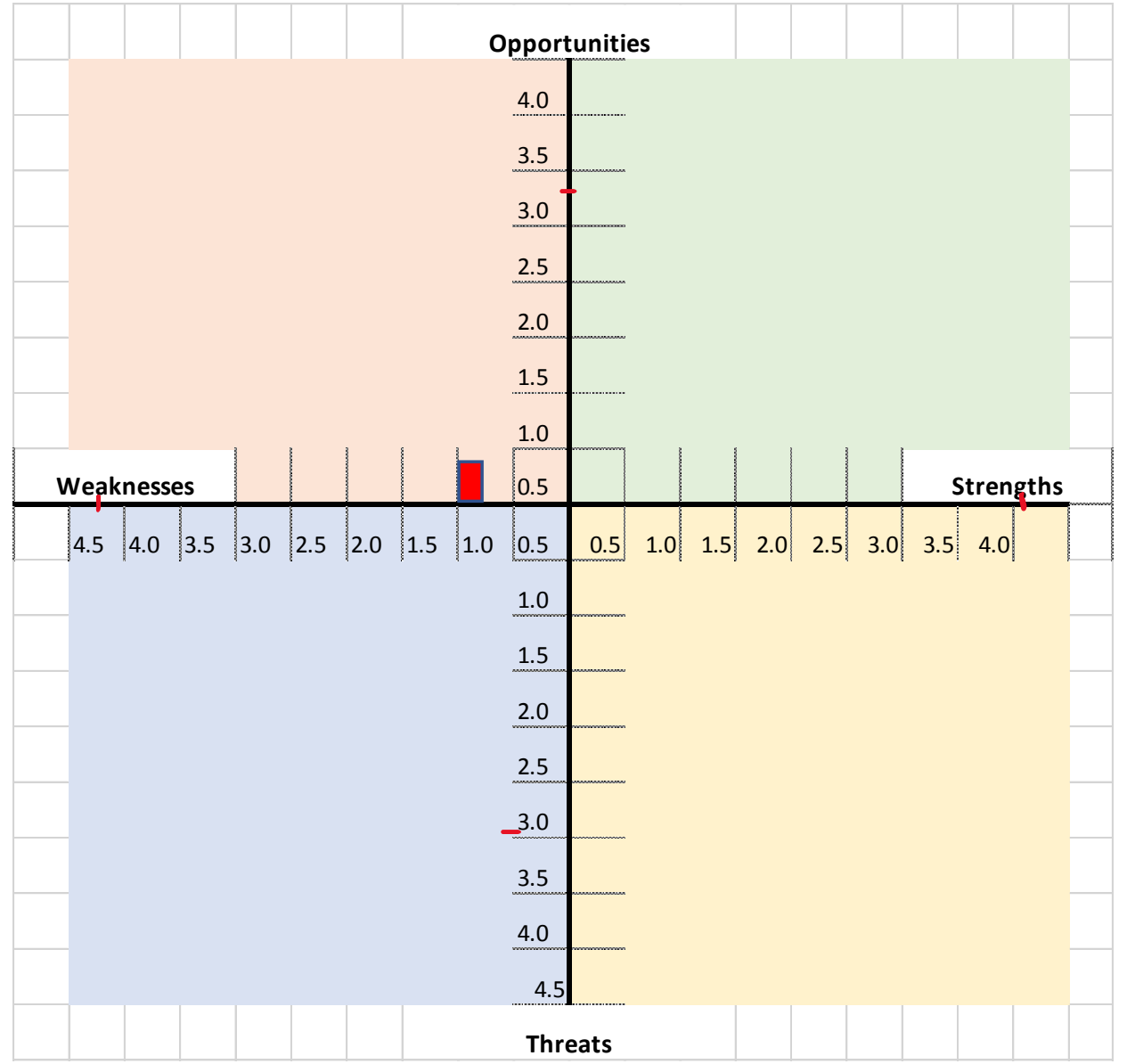

Figure 1. Coordinate Matrix showing the results of the SWOT analysis. Coordinate Matrix adapted from Chang and Huang (2005)

A thorough analysis of the data shows that having subject knowledge is not enough at the tertiary level. It is seen that the existence of the real-life world and practice should be incorporated into the curriculum of the subjects and should be presented to students in addition to the academic or theoretical subjects.

Regarding the language level of the respondents, it ranges from $\mathrm{A} 2$ to $\mathrm{C} 1$, which gives a realistic picture of the current state when there are some teachers with very limited languages skills. Even though they understand the importance and necessity of English, they have not started learning it to a satisfactory level so far. Therefore, to start learning the language, they would need a stronger push or strict requirement from the employer, who focuses more on publishing than on teaching status. What is seen as necessary is that they want to learn or improve the language, especially the productive skills, quite often in cooperation with the language centres.

Cooperation is another striking finding. The need and zeal for cooperation among the subject teachers, language teachers, school departments for international mobilities, methodological centres, even practicallife companies appear in all three groups at numerous moments. Working on the methodological preparation 
and "methodological updating" stands out of all respondents' views. What needs to be stressed is that the methodological courses should be tailored to the needs of tertiary education, which is different from primary, secondary, and even from andragogy. Other important views include the university's relationship with teachers, which plays a significant role in teachers' motivation. The teachers call for the appraisal of their extra work when implementing modern didactic approaches.

The final finding is the preparedness of students for their university studies. It is considered an outside threat as the preparedness decreases in several dimensions (motivation, general knowledge, and language skills) and might affect the success of CLIL dramatically.

The two interviews with the representatives of the school management brought the following findings:

- the applicant for the position of teacher of specialised technical subjects should have pedagogical education. If they do not, they are offered the 2-year pedagogical training course provided by the outsourced yet specialised institution. Furthermore, updating or specialised methodological training for teachers is not offered, neither required.

- The feedback on quality instruction is evaluated (if wanted) based on students' replies in the Teacher Evaluation Form within the University Information System or the superior's opinion (usually, the head of a department). Outstanding performance in the pedagogical process is awarded by the Prize of Jan Amos Comenius once a year.

- Bilingual teaching is not required nor monitored. It is based on a personal initiative. The language abilities of the employees are checked only at the job interview, i.e., once in 2-5 years; only in the written form. The employees must answer questions in the 1-page extent. No other language skills are checked.

- The school management can make some interventions or impose requirements on further education of the employees regarding their language or didactic education.

So, the answers to the research questions are as follows:

\section{Are professional teachers ready to implement CLIL methodology into their teaching?}

The teachers are partly ready to implement CLIL into their teaching. Some of them whose English level is sufficient, i.e., at level B1-B2 of the CEFR, are ready and willing to implement CLIL into their teaching.

\section{What are their strengths to support the implementation of CLIL?}

The main asset of the teachers is their positive attitude towards CLIL. As they all understand the importance and need of English for teachers and tertiary students, they all accept the urge to use English in their content subject. The further investigation shall be completed on the percentage of language part within the disciplinary subjects. Another supporting argument points out the acceptance of cooperation with mainly but not limited to language teachers.

\section{Which weaknesses of teachers need to be dealt with to implement CLIL?}

The SWOT analysis revealed that the main weakness is language skills, namely the ability to speak or use English as the medium of instruction. Most of the teachers use English in writing and reading foreign literature to learn the latest scientific findings. However, they need to gain confidence in speaking in front of students, which sometimes causes speaking anxiety.

\section{Are there any other parameters that might affect the implementation of CLIL at the tertiary}

\section{level of education?}

Putting the results of SWOT analysis and two additional interviews together, we may state that there is a significant input of the university management in the successful implementation of CLIL for providing language courses and methodological update courses to maintain an excellent professional level of university teachers. Additionally, the situation might be significantly affected by decreasing the level of language skills and students' motivation to study at a university. Another aspect shows that there is a niche in teachers training colleges to introduce the subject of CLIL instruction in the pedagogical curriculum of future disciplinary teachers.

Regarding the methodological background, the results show that there is also a niche in methodological support to the university teachers. Even when given, it is often considered formal and unrelated to the practical needs of university teachers. The aspects mentioned by other authors (Haukas, Mercer, and Svalberg, 2021) pointing at the teacher's and students' language anxiety can be seen as the weakness for most tertiary teachers.

One of the possible threats mentioned in the SWOT analysis was decreasing level of preparedness s of students in terms of motivation and language can be helped by the efficient CLIL or ESP instruction as mentioned in the study of Arnó-Macià et al. (2020). The study focused on the perceptions of students on ESP course efficacy, which revealed overall satisfaction with English-taught courses and greater awareness of the 
nature of technical communication and yielded more profound insights into students' strategies. The data stemmed mainly from surveys administered at the start and the end of an ESP course at three universities.

On the other hand, the wishes for cooperation with language teachers and collegial teamwork (Mesmaeker and Lochtman, 2014) are shared across the educational levels and the desire to get more literature and information sources informing the teachers on innovative approaches and CLIL.

Nevertheless, another aspect that is not precisely mentioned in the CLIL 3-dimension profile is the effect of the school management. Some of the responses included the notion of school/university intervention, whether in the form of appraisal or a formal requirement necessary to make the change, meaning the implementation of CLIL, happen. As Quality Educators (Education International, 2011, p. 50) say, "change cannot be successful without stakeholders feeling ownership towards it. Although disagreement exists on the level/intensity of participation, in most of the case studies, the MoE, unions, the profession, academics, and other sector organizations have at some point been involved. Interestingly, parent and student organizations are not necessarily part of the process of development of the CPs." It is natural that at the university level, the communication with parents is not appropriate anymore; however, the student organizations hold a solid position at universities but rarely affect the way and the orientation of the university education. Nevertheless, they might have a word in fostering the quality of education, which is connected to introducing language and content integrated learning.

This research is a partial study of research that aims at the potential of CLIL implementation at the Technical University in Zvolen from the students, teachers, and management.

\section{Limitations}

We tried to apply a genuine and objective approach in the research. However, the advantage of personal judgment and understanding may not work for the objectivity of the research. Therefore, the following drawbacks of SWOT analysis appear rather naturally - all the key factor ratings are measured subjectively (e.g., 1-5 points). Therefore, objective and quantified data are lacking. Chang and Huang (2006) suggested adding quantitative descriptive data.

Regarding this research, the cure could be to add some quantitative data to individual factors, such as the number of available language courses completed or available, the number of foreign study stays attended by teachers or students, the number of international students in the course, the data on the language level of students enrolled in the university studies. The last-mentioned quantitative data could answer the question on the decreasing language level of freshers - the more extended period monitored, the more reliable data achieved. Secondly, non-uniformity may occur when answering the same question because the key factor weights are scored subjectively by the evaluation group without a consistency test. As Yu Bin (2014, p.2) suggests, the SWOT analysis can be improved by conducting AHP (analytic hierarchy process), including calculation of the Consistency Index (CI), Random Index (RI), Consistency Ratio (CR).

The number of participants in this research also needs to be addressed. In general, increasing the number of participants would improve the reliability of the results. Moreover, dividing them according to a different criterion such as the level of language mastering, the home institution, the academic rank, experience with foreign work stays would not have to bring the same results as the division of the participants into groups according to the criterion of the length of their pedagogical experience. However, regardless of the group division, all answers were recorded and placed into the SWOT matrix.

\section{Conclusions}

The research which dealt with the implementation of CLIL at the tertiary level investigated the CLIL teacher profile. Based on the SWOT analysis of the interviews of university teachers with various lengths of teaching practice (from 1 to 35 years), academic rank (Ph.D. students to professors), and level of English according to CEFR (A1 to $\mathrm{C} 1$ ). We came to the following conclusions:

- content knowledge is connected not only to knowing the state-of-art information but also having the experience and understanding of real-life practice,

- language knowledge remains a weakness and needs to be addressed with great attention to achieve level B1-B2 necessary for the implementation of bilingual education,

- university teachers are willing and eager to learn methodology useful for CLIL implementation,

- a real threat is the decreasing level of knowledge, motivation to study, and language mastery of Slovak students enrolling in university,

- the intervention of the university management can have significant effects regarding the international students' presence, Erasmus stays and requirements on and consequent appraisal for the execution of bilingual or team teaching, 
- there is a niche for pedagogical institutions to supply and tailor methodological courses for university teachers.

The results of follow-up research might be different because they would be strongly affected by having a positive or negative experience with team teaching or introducing CLIL activities into lessons.

\section{Acknowledgements}

The research was conducted within the grant project of the Slovak Ministry of Education, Science, Research and Sport KEGA - Support of Foreign Language Education via Merging Technical and Language Content Teaching at Non-Philological Universities No. 003TU Z-4/2020. We are also grateful to the representatives of the Technical University in Zvolen Human Resources Department and Vice-rector for Pedagogical Work for being helpful and informative towards the research.

\section{References}

Alcantud Díaz, M., \& Soler Pardo, D. (2020). Communicative English Language Skills Improvement Programme (CELSIP). Retrieved from https://roderic.uv.es/handle/10550/73114

Alneyadi, S. (Oct. 2021). High School Science Teachers' Professional Development Experiences in the United Arab Emirates. Journal of Science Teacher Education. https://doi.org/10.1080/1046560X.2021.1989643

Ball, P. K., Kelly, K., Clegg. J. (2015). Putting CLIL into Practice. Oxford University Press.

Bin, Yu. (2014). A Novel Method of Real Estate Development Project's Feasibility Research Based on SWOT Method and Analytic Hierarchy Process. International Journal of Business and Social Science, 5(5), $233-237$. https://ijbssnet.com/journals/Vol_5_No_5_April_2014/29.pdf

Cinganotto, L. (2016). CLIL in Italy: A General Overview. Latin American Journal of Content and Language Integrated Learning, 9(2). https://laclil.unisabana.edu.co/index.php/LACLIL/article/view/7177

Cohen, L., Manion, L., \& Morrison, K. (2007). Research methods in education (6th ed.). Routledge/Taylor \& Francis Group.

Coonan, C. M. (2017). CLIL Teacher Education: Issues and Direction. Language Teacher Education, 4 (2). http://www.waseda.jp/assoc-jacetenedu/VOL4NO2.pdf

Coyle, D., Hood, P., \& Marsh, D. (2010). CLIL: Content and Language Integrated Learning. Cambridge University Press.

Chang, H. - Huang, W-Ch. (9th August 2006). Application of a quantification SWOT analytical Method. Mathematical and Computer Modelling, 43, 158-169 https://doi.org/10.1016/j.mcm.2005.08.016

Chmelíková, G., \& Hurajová, L. (November 2019). ESP Teachers in the world of globalisation and higher education internationalisation. The Journal of teaching English for Specific and Academic Purposes, 7(4), 443-452. https://doi.org/10.22190/JTESAP1904443C

D'Alessio, G. \& Hardie, J. (2019). Implementing CLIL at University Level. INTED2019 Proceedings, 6318-6323. http://dx.doi.org/10.21125/inted.2019.1537

Education International, Oxfam Novib. (May 2011). Quality Educators: An International Study of Teacher Competencies and Standards. Education International - Resources and Research: https://www.ei-ie.org/en/item/18115:ei-and-oxfam-launchthe-quality-educators-for-all-programme

European Centre for Modern Languages of the European Council (2004-2007). CLIL Matrix. Content and Language Integrated Learning. https://www.ecml.at/Resources/ECMLresources/tabid/277/ID/42/language/en-GB/Default.aspx

Eurydice (2013). The Italian Educational system. https://www.indire.it/lucabas/lkmw_file/eurydice///sintesi_sistema_educativo_italiano_EN.pdf

Fardani, I. A., Agustina I. H., Jauzi., F A. (2020). Implementing SWOT analysis in engineering education. IOP Conference Series: Materials Science and Engineering, 830(3). https://iopscience.iop.org/article/10.1088/1757-899X/830/3/032066

Flick, U. W. E. (2009). An introduction to qualitative research. London: SAGE Publishing.

Furgison, L. (2019). SWOT Analysis Step 5: Developing Actionable Strategies. Bplans. https://articles.bplans.com/swot-analysischallenge-day-5-turning-swot-analysis-actionable-strategies/

Haukas, A., Mercer, S., \& Svalberg, A. (2021). School Teachers' Perceptions of Similarities and Differences between Teaching English and a Non-Language Subject. TESOL quarterly, 1-25. https://onlinelibrary.wiley.com/doi/10.1002/tesq.3062?af=R

Hergüner, B. (2021). Rethinking public administration education in the period of pandemic: Reflections of public administration students on online education through a SWOT analysis. Thinking Skills and Creativity, 41. http://dx.doi.org/10.1016/j.tsc.2021.100863

Hurajová, L. (2021). Can Close Cooperation Between ESP/CLIL Experts And Disciplinary Teachers in Higher Education Lead to Fostering English Education Environment. Journal of Teaching English for Specific and Academic Purposes, 9(1), 129136. http://dx.doi.org/10.22190/JTESAP2101129H

Hurajová, L., \& Luprichová, J. (2017). CLIL - Potential Way of Enhancing Internationalization of Higher Education in Diverse Context. International Conference ICT for Language Learning. Florence: ICT. https://conference.pixelonline.net/ICT4LL/files/ict411/ed0010/FP/3016-CLIL2739-FP-ICT4LL10.pdf

Infante, D., Benventuto, G., \& Lastrucci, E. (2009). The Effects of Clil from the Perspective of Experienced Teachers. In David Marsh et al.(Eds.), CLIL Practice: Perspectives from the Field. Finland: University of Jyväskylä. https://research.nu.edu.kz/ws/portalfiles/portal/16933776/CLIL_Practice_Perspectives_from_the_Field.pdf

Kenton, W. (2021). Strength, Weakness, Opportunity, and Threat (SWOT) Analysis. Investopedia. https://www.investopedia.com/terms/s/swot.asp

Kováčiková, E. \& Prokeinová,R. (2012). Focus Group in Educational Research. In Silvia Pokrivčáková (Ed.), Research in Foreign Language Education (pp.62-87). Brno: MSD. 
Kováčiková, E. (2020). English for Specific Purposes in Higher Education through Content and Language Integrated Learning. Cambridge Scholar Publishing.

Lonhgurst, G. J., Stone, D. M., Dulohery, K. Scully, D., Campbell, T. \& Smith, C. F. (2020). Strength, Weakness, Opportunity, Threat (SWOT) Analysis of the Adaptations to Anatomical Education in the United Kingdom and Republic of Ireland in Response to the Covid-19 Pandemic. Anatomic Science Education, 13(3), 301-311. https://doi.org/10.1002/ase.1967

Marsh, D. (2013). The CLIL trajectory: Educational innovation for the 21 st century iGeneration. Universidad de Córdoba- Servisio de Publicaciones.

Mehisto P., Marsh D.; Frigols M. J. (2008). Unocovering CLIL: Content and Language Integrated Learning in Bilingual and Multilingual Education. Macmillan Education.

Mesmaeker, E. D., \& Lochtman, K. (2014). Belgian CLIL Teachers' Professional Identity. In Dagmar Abendroth-Timmer and EvaMaria Hennig (eds.), Plurilingualism and Multiliteracies - International Research on Identity Construction in Language Education (pp.191-210). https://library.oapen.org/bitstream/handle/20.500.12657/31572/626988.pdf?sequence=1\#page=193

Meyer, O. (2010). Towards quality CLIL: Successful planning and teaching startegies. Puls,10, 11-29. https://revistas.cardenalcisneros.es/index.php/PULSO/article/view/92

Novotná, J., Hadj-Mousssová, Z., \& Hoffmannová, M. (2001). Teacher Training for CLIL - Competences of a CLIL Teacher. Proceedings SEMT. https://people.fjfi.cvut.cz/novotant/jarmila.novotna/novotna-et-alsemt01.pdf

Shewan, D. (16. March 2021). How to Do a SWOT Analysis for Your Small Business (with Examples). WordStream. https://www.wordstream.com/blog/ws/2017/12/20/swot-analysis

Turek, I. (2010). Didaktika. Iura Edition.

Váchal J, \& Vochozka, M. (2013). Podnikové ř́zení. Grada Publishing.

Wheelen, T. \& Hunger, D. (13th edition 2012). Strategic Management and Business Policy. Malawi Institute of Management. http://www.mim.ac.mw/books/Wheelen's\%20Strategic\%20Management.pdf

Yang, W. (2016). An Investigation of Learning Efficacy, Management Difficulties and Improvements in Tertiary CLIL (Content and Language Integrated Learning) Programmes in Taiwan: A Survey of Stakeholder Perspectives. Latin American Journal of Content \& Language Integrated-LACLIL, 9(1), 64-109. http://dx.doi.org/10.5294/lacli1.2016.9.1.4

Yang, W. (2018). Evaluating Contextualized Content and Language Integrated Learning Materials at Tertiary Level. LACLIL, 11(2), 236-274. http://dx.doi.org/10.5294/laclil.2018.11.2.4 